\title{
A case of solitary plasmacytoma of the mastoid bone presenting as coalescent mastoiditis
}

\author{
Koalesan mastoidit kliniği oluşturan mastoid kemiğin soliter \\ plasmositomu vaka sunumu
}

Cigdem KAFKASLI ${ }^{1}$, M. Tayyar KALCIOGLU², Fatih Mehmet HANEGE ${ }^{3}$, Tulay ZENGINKINET ${ }^{4}$, Lokman UZUN ${ }^{5}$

ABSTRACT

Squamous cell carcinoma, lymphoma, plasmacytoma and metastatic tumors can be seen in the mastoid bone as is the case with prostate or lung tumor. Plasmacytomas are rarely seen plasma cell tumors of the mastoid bone. In this case presentation, a 34-year-old patient who applied to our hospital with mastoiditis symptoms, who had undergone mastoidectomy and diagnosed with localized plasma cell lambda monoclonal neoplasia of mastoid bone was presented. Malignancies such as solitary plasmacytoma should be kept in mind and pathological evaluation of surgery materials should be remembered in the differential diagnosis of coalescent mastoiditis. Otherwise, treatment will be inevitably inadequate.

Key words: Extramedullary plasmacytoma; mastoid bone; mastoiditis, coalescent
Öz

Prostat ya da akciğer tümörlerinde olduğu gibi mastoid kemikte de skuamöz hücreli karsinom, lenfoma, plazmositoma ve metastatik tümörler görülebilir. Plazmositomalar mastoid kemiğin plazma hücreli tümörlerinin ender bir türüdür. Bu vaka sunumunda mastoidit semptomlarıla kliniğimize bașvuran ve mastoidektomi operasyonu sonrası mastoid kemiğin lokalize plazma hücreli lambda monoklonal neoplazisi tanısını alan 34 yaşında hasta sunuldu. Soliter plazmositoma gibi maligniteler cerrahi materyallerin patolojik değerlendirmeleri yapılırken koalesent mastoidit ayırıcı tanısında akılda bulundurulmalıdır. Aksi takdirde, tedavi kaçınılmaz olarak yetersiz kalacaktır.

Anahtar kelimeler: Ekstramedullar plazmositoma, mastoid kemik, mastoidit, koalesan

\section{INTRODUCTION}

Plasma cell tumors of the mastoid bone are rare malignancies of hematological origin ${ }^{1}$. Plasma cell neoplasms can be classified into following types: extramedullary plasmacytoma, solitary plasmacytoma of the bone, multifocal form of multiple myeloma, multiple myeloma and plasmablastic sarcoma ${ }^{2}$. Solitary plasmacytomas are rare and account for $4 \%$ of the plasma cell tumors. Solitary plasmacytomas originate from the bone marrow and they are characterized by bone erosion, whereas extramedullary plasmacytomas originate from submucosal layer without involvement of bone ${ }^{2}$. Diagnosis is made by demonstrating the monoclonal cells dominating in matrix during the immunohistochemical examinations ${ }^{1}$. Opacification and coalescence are observed in air cells in computed tomograms (CT). However, this image is non-specific and may be seen in patients with infections and tumors. Magnetic resonanance imaging (MRI) helps by distinguishing the presence or absence of soft tissue mass with its tissue signal properties ${ }^{3}$. Multiple myeloma should be considered in all patients diagnosed with plasmacytoma. In this case report we presented a patient who applied to our clinic with symptoms of acute mastoiditis; redness and swelling in the left mastoid region and histopathologically diagnosed as "plasma cell lambda monoclonal neoplasia" after mastoidectomy surgery.

Received: 18.08 .2015

Accepted: 01.10.2015

${ }^{1}$ Resident; ${ }^{2}$ Professor; ${ }^{3}$ Specialist; ${ }^{5}$ Associate Professor, Department of Otorhinolaryngology, Specialist, Department of Pathology, İstanbul Medeniyet University Medical Faculty, Goztepe Training and Research Hospital

Yazışma adresi: M. Tayyar Kalcioglu, İstanbul Medeniyet University Medical Faculty, Department of Otorhinolaryngology, Kadıköy, İstanbul

e-mail: mtkalcioglu@hotmail.com 


\section{CASE PRESENTATION}

A 34-year-old male patient applied to our clinic with complaints of redness and swelling behind the left ear. In the last two weeks, the patient applied to different hospitals with these complaints and diagnosed with infection but he did not receive any treatment. On physical examination, a hyperemic, painful, soft inflamed area was determined on the left mastoid bone. Tympanic membranes were bilaterally normal in otoscopic examination. Temporal bone CT revealed

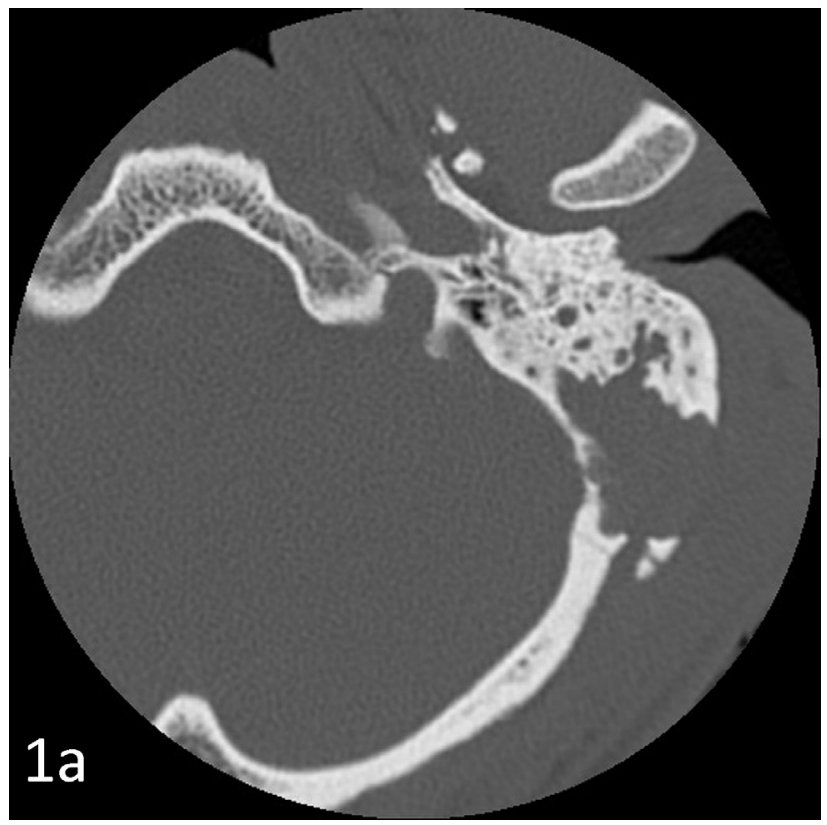

Figure 1a. Computed tomography of temporal bone. Nonpneumatization of left mastoid, fill of the tympanic cavity with bone erosions.

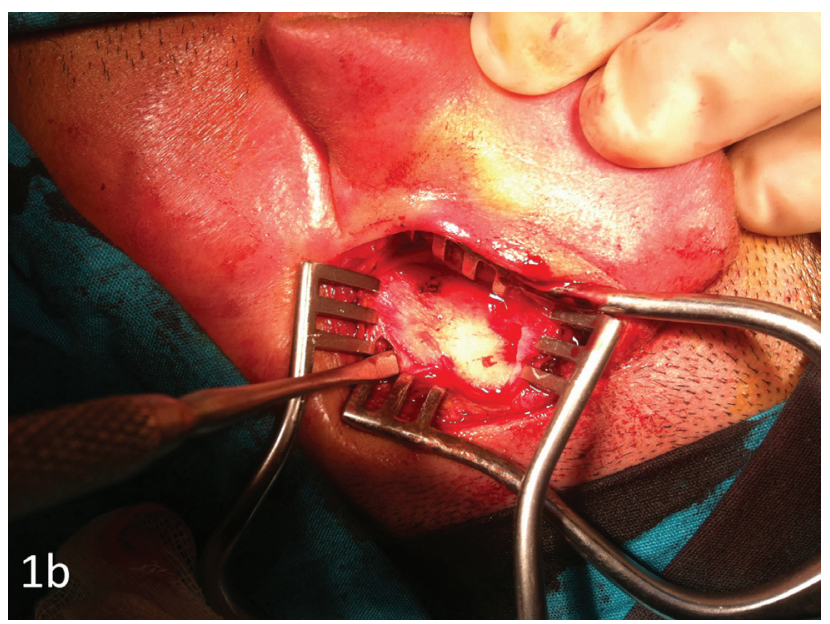

Figure 1b. Partially eroded mastoid cortex. defects both in the external and internal sides of the bone cortex at the postero-inferior part of mastoid cells and a hypodensity with a size of $27 \times 18 \mathrm{~mm}$ on the left side. Thickening was observed below the adjacent skin-skin and muscular and facial planes, and it was reported as "primarily indicating local infection fistulized to soft tissue, but a tumoral mass lesion can not be excluded conclusively" by the radiologist (Figure 1a). Thereon, diagnostic and therapeutic left mastoidectomy was performed. During the surgery after the incision in the left retroauricular region, the skin and the subcutaneous tissues were elevated to approach to the mastoid cortex and partial erosion was observed in the cortical bone (Figure 1b). Pathologic tissues resembling granulation tissue were removed from the mastoid region with mastoidectomy. Inferior mastoid bone was completely eroded. Cavity cleaned up completely. All of the removed tissues were sent for pathologic examination. After the control of the bleeding with Surgicel surgery was terminated. Histopathologic examination was reported as "plasma cell dyscrasia" (Figure 2a-c). Then, multiscan imaging was performed for multiple myeloma. Cervical, thoracic, pelvic and spinal MRIs were considered as normal. Positron Emission Tomography (PET)-CT any evidence of tumor. Bone marrow aspiration biopsy was considered to be normal. Thus, diagnosis of multiple myeloma was excluded. Solitary plasmacytoma is considered as a low risk disease because of the small size of the tumor $(<4 \mathrm{~cm})$, presen-

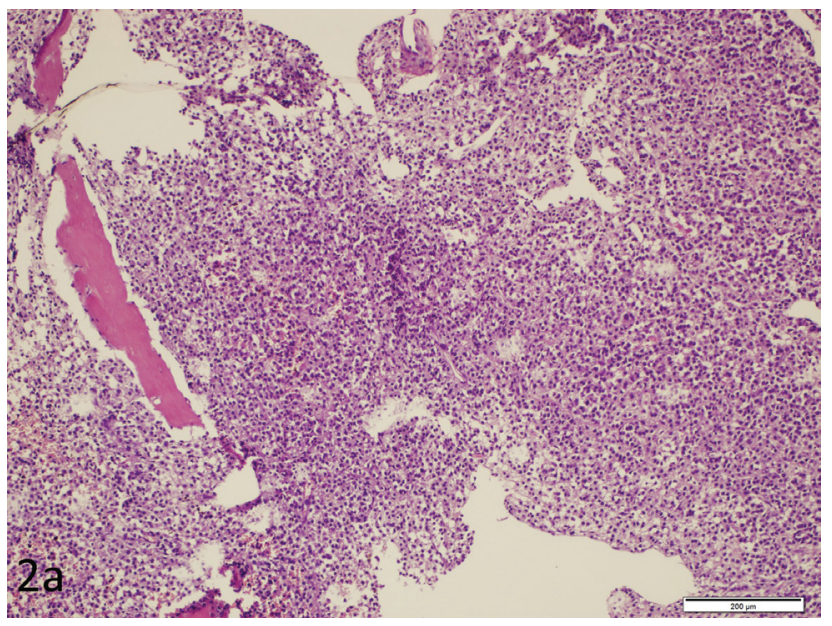

Figure 2a: Diffuse atipical plasma cell infiltration around a small part of bone (H\&E, 20X). 


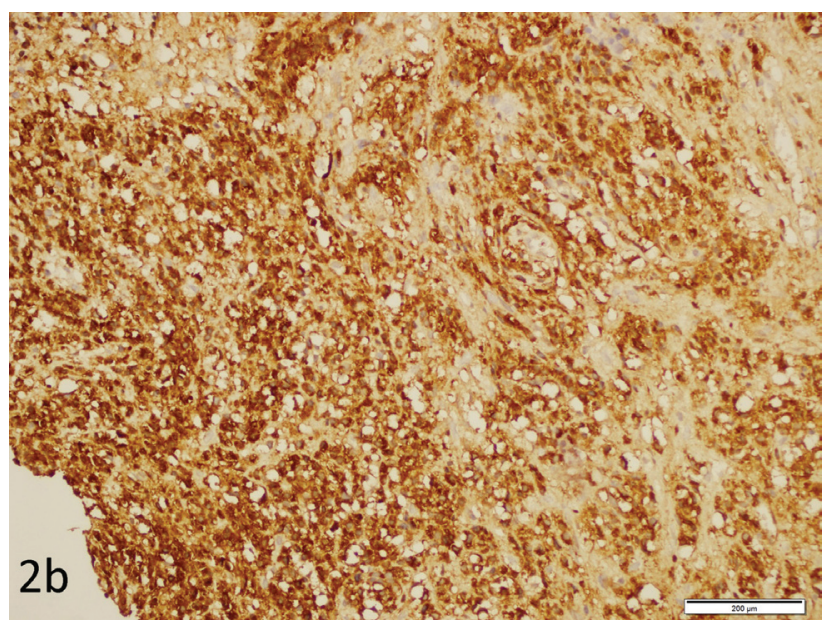

Figure 2b. Strongly diffuse positive immunoreactivity by CD 38.

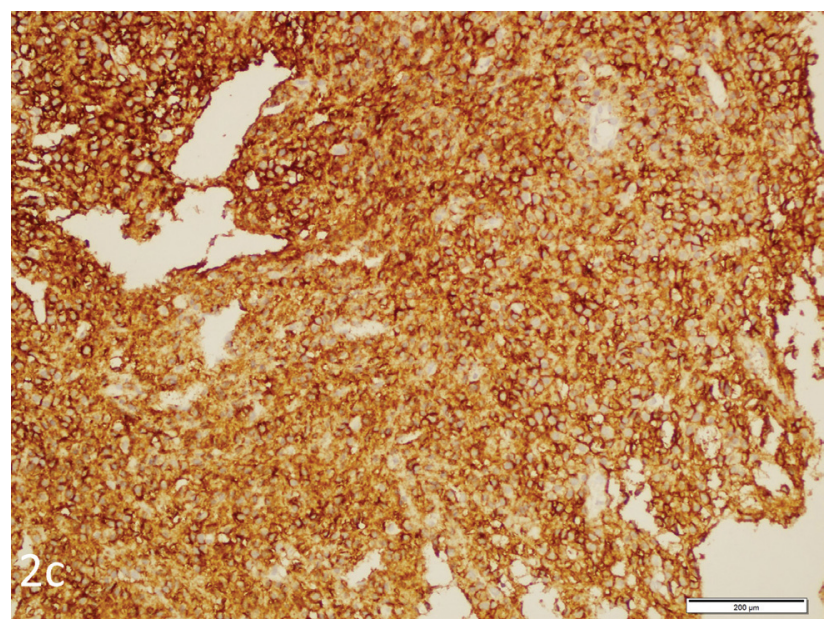

Figure 2c. Strongly diffuse positive immunoreactivity by Lambda.

ce of unique lesion, absence of accompanied $\mathrm{M}$ protein and plasma cell ratio of bone marrow $(<10 \%)$. Radiotherapy was recommended to the patient as treatment modality, and 5000 Gray radiotherapy was administered to the patient for 25 sessions. Any evidence indicating tumor recurrency or persistency at 18 month after surgery by PET-CT control scan could not be detected.

\section{DISCUSSION}

Plasmacytomas are malignant plasma cell tumors characterized by proliferation of plasma cells and production of monoclonal immunoglobulin. Morphology appears as soft tissue or bone ${ }^{4}$. Bone plasmacytomas are usually primary, whereas extra- medullary plasmacytomas typically originate from adipose, muscular or mucosal surfaces and more than $80 \%$ of the extramedullary plasmacytomas are seen above diaphragm, in respiratory system, gastrointestinal tract and also head and neck area ${ }^{5}$. Solitary plasmacytomas are seen in the age group of 50-70 years and occur more often in women than men ${ }^{1}$. Our case was a young man. Although the risk factors for plasmacytomas are not known, exposure to radiation was suggested to be a risk factor ${ }^{6}$. There is no radiation exposure in the history of our case.

As with all tumors, cases with plasmacytoma may also show lymph node positivity during the onset of disease or relapse. About $40 \%$ of cases may show lymph node positivity ${ }^{7}$. Lymph node positivity was not detected in our case both during examination and PET-CT assessment.

Radiologically solitary plasmacytoma may appear as unilocular, lytic lesions or multicystic expansile lesions and may mimic the giant cell tumors. CT and MRI images do not allow for a detailed definition. Typical osteolytic skull lesions, the 'perforation appearance'like findings may be detected in multiple myeloma. Discrimination between the tumor and the fluid is ensured by the hypointense appearance of mass compared to fluids in T2 weighted MR images of solitary plasmacytoma and a homogenous involvement is observed in the mass after intravenous contrast administration ${ }^{3}$. Preoperative radiological assessment of our case was interpreted as local infection.

Malignancies such as plasma cell leukemia, Waldenström's macroglobulinemia, low-grade nonHodgkin lymphoma and extramedullary plasmacytomas should be excluded in the differential diagnosis of solitary plasmacytomas ${ }^{2}$. In our case, diagnosis was confirmed as "plasma cell lambda monoclonal neoplasia" following the histopathologic examination and appropriate treatment protocol was administered.

Treatment of solitary plasmacytoma includes surgical excision and radiotherapy. Solitary plasmacytomas 
are radiosensitive tumors and respond well to radiotherapy. Radiotherapy at doses of 4000-6000 Gray is used as adjuvant therapy. In our case, radiotherapy at a dose of 5000 Gray was administered for 25 sessions after extended surgical resection. Relapse was not detected at postoperative one year examination and PET-CT assessment.

Malignancies such as solitary plasmacytoma should be kept in mind and pathological evaluation of surgical materials should be done in differential diagnosis of coalescent mastoiditis. Otherwise, treatment will be inevitably inadequate.

\section{Conflict of Interest}

Because of one the co-authors is a member of the journal's editorial board, he has been excluded from evaluation processes of the manuscript for publication.

\section{REFERENCES}

1. Kandiloros DC, Nikolopoulos TP, Ferekidis EA, et al. Primary extramedullary plasmacytoma in the middle ear: differential diagnosis and management. J Larygngol Otol 1994;108:868-70. http://dx.doi.org/10.1017/s002221510012835x

2. Markou K, Karasmanis I, Goudakos JK, et al. Extramedullary plasmacytoma of temporal bone: report of 2 cases and review of literature. Am J Otolaryngol 2009;30:360-5. http://dx.doi.org/10.1016/j.amjoto.2008.07.004

3. George JC,Caldemeyer KS, Kreipke DL, et al. Solitary plasmacytoma of the mastoid bone presenting as coalescent mastoiditis. Arch Otolaryngol Head Neck Surg 1994;120:1393-4. http://dx.doi.org/10.1001/archotol.1994.01880360085015

4. Dimopoulos MA, Kiamouris C, Moulopoulos LA. Solitary plasmacytoma of bone and extramedullary plasmacytoma. Hematol Oncol Clin North Am 1999;13:1249-57. http://dx.doi.org/10.1016/S0889-8588(05)70124-6

5. Wiltshaw $\mathrm{E}$. The natural history of extramedullary plasmacytoma and its relation to solitary myeloma of bone and myelomatosis. Medicine (Baltimore) 1976;55:217-38. http://dx.doi.org/10.1097/00005792-197605000-00002

6. Knowling MA, Harwood AR, Bergsagel DE. Comparison of extramedullary plasmacytomas with solitary and multiple plasma cell tumors of bone. J Clin Oncol 1983;1:255-62.

7. Hu K, Yahalom J. Radiotherapy in the management of plasma cell tumors. Oncology (Willston Park) 2000;14:101-8. 